\title{
An Abridged Welfare-State Minded Introduction to the "Art” of Microeconomics
}

\section{Gerasimos T Soldatos*}

American University of Athens, Greece

${ }^{*}$ Corresponding author: Gerasimos T Soldatos, Professor, American University of Athens 3, Kodrou str. Halandri, Athens 15232, Greece, Tel: +1334-834-7748; E-mail: soldgera@yahoo.com

Rec date: Oct 02, 2016; Acc date: Oct 20, 2016; Pub date: Oct 27, 2016

Copyright: () 2016. Soldatos GT. This is an open-access article distributed under the terms of the Creative Commons Attribution License, which permits unrestricted use, distribution, and reproduction in any medium, provided the original author and source are credited

\begin{abstract}
This is an abridged set of notes on an introductory course in microeconomics designed to show how the welfare state is the only way to reconcile the central conclusion of this discipline, namely the harmony of consumer sovereignty, with the disharmony of capitalism especially when the need for merit goods is acknowledged. The first part of the paper presents the basic ingredients needed to have consumer sovereignty when only private goods are considered, and then characterizes consumer sovereignty in the presence of market failures and public goods, too. The second part introduces into the discussion merit goods preparing the ground for the conclusion that only the welfare state can alleviate the antithetic trends of capitalism and foster consumer sovereignty as a second-best approach to the system even when merit goods are present. It does so by noting that either the unfettered capitalism of globalization or the interventionist socialist market can be exploited politically and upset the system. The embedded liberalism of welfare state as the only successful means of "managed disharmony" is then concluded in the last section of these notes.
\end{abstract}

Keywords: Introduction to microeconomics; Political economy; Consumer sovereignty; Merit goods, Welfare state

\section{Introduction}

In the beginning, that is, at the times of Adam Smith [1,2] and David Ricardo [3], economics was political economy, that is, interdisciplinary social science, economics-sociology-political science together, so to speak, acknowledging the antithetic character between labor wages and capitalist profits. Then, the sociopolitical element in Economics gave gradually way to the study of the behavior of individuals away from socioeconomic class considerations. This type of study came to be called "microeconomics" whose mathematized character in an analytical context capable of combining positive and normative statements, contributed further to the subsidence of attention from the antithetic forces of the system.

Yet, as we shall see in due course below, this analytical context which makes Microeconomics be an "art" rather than a strictly scientific discipline, does manage to provide the recipe for a managed disharmony of the system to the interest of all socioeconomic classes. It does so by highlighting the merits of the so-called welfare-state or mixed-economy, which compromises purposeful government intervention and individual liberties in line with John Maynard Keynes' "post-WWII embedded liberalism", having lasted until the late 1970s.

But, the "artistic" character of microeconomics can always be manipulated to advance macroeconomic theses, that is, views about the behavior of the overall economy and macroeconomic policies that can upset any compromise and revive disharmony to the interest of a particular socioeconomic class. Excessive demands on the part of organized labor led the mixed economy to a crisis which in the late 1970s and early 1980s gave way to excessive demands on the part of capitalists, and the welfare state collapsed; demands justified theoretically by manipulating the normative aspect of microeconomics in any case.

In what follows, the teaching of microeconomics is approached from this political economy point of view. The next section focuses on the combination of the positive and the normative needed to characterize system harmony in an all-private goods market economy. Section 3 points to market failures as the source of corrective government intervention and characterize harmony in the presence of such a government as well. Section 4 notes the discrepancy between reality and these theoretical results, the feasibility still of harmony theoretically from the viewpoint of second best, and points to the presence of merit goods that can upset fully the system. Section 5 concludes this paper by pointing to the welfare-state compromise as the only way to salvage the system.

\section{The "Art" of Microeconomics I: The Market and the Private Sector}

\section{Normative desiderata}

The key normative microeconomic concept relating the scarcity of resources and choice of what, how, and for whom to produce with these resources, is the opportunity cost. It is defined to be the "implied cost of an action" not reflected in accounting costs but implied by the benefit foregone from not having chosen the best alternative action.

And, the key behavioral assumption about decision-makers is that they are rational, that is, (a) have perfect information about the set of alternatives open to them, which is the choice set, (b) can compare all alternatives with each other, (c) can infer that if alternative $A$ is preferred to $\mathrm{B}$, and alternative $\mathrm{B}$ is preferred to $\mathrm{C}$, then $\mathrm{A}$ is preferred to $\mathrm{C}$, and (d) choose actually the most preferred alternative from his/her choice set. 
Page 2 of 5

So, given rationality and based on the notion of opportunity cost: (I) The choice problem of what mix of goods to produce ought to be solved in a manner that a change of this mix would make at least one consumer worse off in term of his/her preferences: consumption efficiency; (ii) The choice problem of how to combine scarce inputs to produce ought to be solved by producing the maximum of the decided mix of goods in a manner that a change in this combination would reduce the output of at least one good: production efficiency; and (iii) the choice problem of for whom to produce ought to be solved by distributing the produced output of a good among its inputs in a manner that a change of the distribution would not reflect one at least input's true contribution to production: functional distributive efficiency.

\section{The satisfaction of the desiderata by the normative free market}

One way to satisfy these desiderata is through the market of a good or input, which is a decentralized medium facilitating the exchange of it between its buyers and its sellers. The exchange need not necessarily involve money. The demand by the buyers and the supply by the sellers determine the price of the traded good according to the laws of demand and supply. Let $\mathrm{P}$ and $\mathrm{Q}$ denote the price and quantity of a good, and the pair $\left(\mathrm{P}^{*}, \mathrm{Q}^{*}\right)$ be the equilibrium price-quantity combination, that is, the pair that clears the market, eradicating excess supply or the same, surpluses, or excess demand, i.e. shortages, in the market.

IF no buyer and no seller can influence market exchange, that is, in the absence of market power-in which case markets are said to be perfectly competitive as opposed to the imperfect competition implied by the presence of market power-the pair $\left(\mathrm{P}^{\star}, \mathrm{Q}^{*}\right)$ will satisfy all three efficiency desiderata for the minimization of the opportunity cost in a Walrasian general equilibrium system. This is what is meant by the terms "free market" and "decentralized exchange". The Walrasian general equilibrium system is the set of the markets of all goods because Q is not the only good in the economy. Assuming absence of market power in general, Walras' law states that an excess demand/ supply in one market is matched by an excess supply/demand of equal value in the other markets. So, if $Q$ is one good and $Q$ is the subset of the remaining goods, the market of $\mathrm{Q}$ cannot be in equilibrium if at least one market in $Q$ is in disequilibrium unmatched by another market in Q.

The Walrasian general equilibrium includes input markets as well so that if labor market, for instance, is in excess demand/supply, the market for $\mathrm{Q}$ will still be in disequilibrium, i.e. excess supply/demand, even if all markets in $Q$ are in equilibrium. The key feature of the Walrasian system is that input and goods prices adjust instantaneously in response to market surpluses or shortages to clear them out and restore the general equilibrium. This price flexibility is an assumption of the analysis, not a normative requirement. It is clear that the satisfaction of the normative concept of efficiency or the same, Pareto optimality, is founded on the positive economics of Walras' law, which is an example, a key one, of "economics as an art".

\section{The free market and (Social) welfare economics}

The following two theorems have been advanced, from this precisely normative, "welfare" point of view:

First fundamental theorem of welfare economics: Perfect competition is Pareto optimal.
Second fundamental theorem of welfare economics: Pareto optimality is attainable by perfect competition under possibly some income redistribution.

The introduction of the matter of income redistribution in the discussion acknowledges that people are not alike. The concept of efficiency downplays the role of this social element in the allocation of resources because it focuses on the individual consumer-laborer and producer. The Walrasian generalization is a straightforward extension of the individual case, leaving intact the social welfare matters of personal satisfaction from one's own income and from the particular piece of the "economic pie" bought as compared to other individuals' income position and consumption baskets. Such comparisons are important welfare-wise and the following two additional desiderata should be satisfied to have optimal both individual and social welfare:

Equity: An income distribution is equitable if everyone values the share of the economic pie bought with his/her income, just as much as anyone else's share.

Envy-freeness: The division of the economic pie is envy-free if everyone prefers his/her own share to the others'

The focus is on the share of the economic pie as a heterogeneous perfectly divisible good, or in technical terms, on cake-cutting, because a piece of the cake is what ultimately a producer claims with his income, i.e. profits, just like any other consumer-laborer wage-earner does. Once the allocation of the limited resources is decided to yield a "cake" complying not only with efficiency but also with equity and envy-freeness, the subsequent cake-cutting is said to be Fair or Perfect. Now, Bram's, et al. [4] showed in AMM that there can be a cake such that no perfect division of it exists for an extension of the division to three or more individuals or groups of identical in income and tastes individuals. So, free Walrasian markets do not necessarily lead to fairness unless two only socioeconomic classes are assumed.

\section{The "Art" of Microeconomics II: Market Failures and the Government}

\section{Market failure I: Public goods}

The decentralized mechanism of the market and subsequently, the welfare desiderata just mentioned, apply to the case of private goods. These are goods that must be bought, become own property, to be consumed (Rivalrous among consumers) and whose buyer can enforce the property right by excluding from consumption any other individual (excludable). But, Figure 1 illustrates that there are four more types of goods:

\begin{tabular}{|l|lll|}
\hline & Excludable & Semi-Excludable & Non-Excludable \\
\hline $\begin{array}{l}\text { Rivalrous } \\
\text { Semi-Rivalrous }\end{array}$ & Private Goods & & Common Goods \\
Non-Rivalrous & Club Goods & Near-Public Goods & \\
& & & Public Goods
\end{tabular}

Figure 1: Five types of goods.

The market cannot provide efficiently any of them; it underprovides them. There is a Market Failure, which can be addressed only in a centralized manner through a collective entity called government, complementing ideally the market economy as follows: In so far as Public Goods are concerned, there are open for all to consume (non- 
Page 3 of 5

rivalrous) without the ability to exclude anyone from its consumption (non-excludable). So, their consumption should be decided by the society as a whole; not by the individual consumer. One task then of a government would be to implement society's decision about the mix of public and "non-public" goods, financing the provision of the decided public goods by income taxation. In so far as common goods are concerned, they are rivalrous but may be overused if property rights are not well defined and appear to be semi-rivalrous, and another task of a government would be to make clear property rights. Regarding club goods, they are excludable and may be delivered by the market, but if they are underprovided due to their non-rivalrous nature, their provision might be complemented through public enterprises set up by the government. And, there are the near- or quasi-public goods, easy to keep people away from them by charging them a price for consuming, but there is no really good reason to do so, and congestion comes up that might be taken care of by the government.

\section{Market failure II: Externalities}

The market provision of private goods may involve Externalities, that is, cost (negative externality) or benefit (positive externality) to market participants, consumers (consumption externality) and producers (production externality), without having the partakers chosen to incur that cost or benefit. If property rights are well defined and if people act rationally, Coase Theorem states that the parties involved can negotiate payments to each other towards an efficient outcome, making government intervention to correct for an externality unnecessary. But, if at least one of these two "ifs" and/or if negotiations are costly, the government may intervene to correct for externalities by taxing and regulating negative ones, and by subsidizing or providing by itself goods with positive externalities. A third type of market failure that might induce the regulatory intervention of the government is buyer-seller Information Asymmetries, when information is not perfect but bounded in the sense that identifying and comparing each alternative against every other may take time, effort, and mental capacity; example: seller knows, buyer doesn't.

\section{Market-cum-government in one normatively ideal economic system: Consumer-laborer-voter sovereignty}

Considering the group of goods and services provided by the government sector as one single good financed through Lindahl taxation, that is, through individual tax payments according to the amount of satisfaction derived from the consumption of an additional unit of this good, the three fairness desiderata mentioned earlier will be holding in so far as all goods, private and the government one, are concerned. Presumably, (A) people reveal truthfully their preferences about the mix between the single government good and private goods as a whole, (B) they reveal them in a decentralized way, that is, democratically, (i) voting over alternative proposals about this mix as presented by political parties and (ii) the elected government keeps its pre-election promises. The government thus respects consumer preferences as much as the market does, which is an ideal socioeconomic state of affairs called Consumer Sovereignty; sovereignty of the consumer-laborer-voter. There is such sovereignty under the ideal type of market we saw earlier, the one in the absence of market power, and under the ideal type of democracy just described.

\section{The "Art" of Microeconomics III: Consumer Sovereignty in Reality}

\section{Consumer sovereignty and facts}

Walras' law holds always, but the general equilibrium may not be a Walrasian one to the extent that is attained through quantity adjustment rather than price adjustment; quantity adjustment leads to Marshallian Equilibria, which are unstable to the extent they are not Walrasian ones.

- Socioeconomic classes are more than two and cake-cutting may not be fair.

- Fairness will not certainly be the case if a government is not willing or let or able to make the income redistribution dictated by the second theorem of welfare economics.

- Much more so when imperfect competition rules the markets in the real world, and government intervention can only moderate it, not eliminate it.

- The market power is mostly with the firms of the sellers, who because of this earn profit higher than that prescribed by functional distributive efficiency; higher profits at the expense of wages, and conferring political power.

- People do not have an incentive to reveal truthfully their preferences about public goods, because non-excludability implies that one can benefit from them without paying the taxes one should; this is the problem of free-riding incapacitating Lindahl or Bowen taxation.

- Nothing prevents a distortion of the election outcome by a minority party that either makes the public reverse its preferences over the two bigger parties or sides with the defeated one to form a majority coalition; phenomena which have led to Arrow's Impossibility Theorem.

And, of course, it would not be rare to see a government breaking its pre-election promises.

So, the system is far from being fair and the consumer-voter sovereignty is questionable.

\section{The theory of second best and weak efficiency}

And, why people should not try to free-ride in order to compensate with the saved taxable income for the reduction of it by their imperfectly competitive employers, who anyway find ways to reduce their own tax responsibilities? Issues like this are very important and very difficult to address in practice. Yet, the government can still do something about at least Pareto efficiency in the sense that it can lead the economy to alternative allocations whose realization would cause every individual to gain. That is, a government can steer the system towards weak only Pareto efficiency; weak, because of less aggregate income relative to the strong Pareto optimality discussed earlier. Government policymaking can do pursue a weak optimum because according to the theory of second best, if the removal of a particular distortion of fairness is not feasible, setting up a second (or more) distortions may offset partly the first, and lead to more at least efficiency.

So, although in reality consumer sovereignty appears to have limited scope, if the government acts as just prescribed, consumer sovereignty cannot be dismissed as a principle deciding the size of the government 
sector and forming the basis of the socioeconomics and politics of the system.

\section{Market failure III: Merit goods and consumer sovereignty}

The optimal private-government sector composition of the economy is even further blurred by the presence of a sixth type of goods, the Merit Goods, provided by the government as it does with public goods. According to Musgrave who first noted in 1959 the special character of these non-excludable too, goods, there are some human needs of such importance that they merit governmental support in the form of inkind distribution of specific goods like housing for the poor, school lunches, maintenance of historical sites, regard for the arts, etc. Some say that the presence of merit wants points to a fourth type of market failure coming out of cases in which individuals are not the best judges of their welfare, because of bounded rationality and information asymmetries as with the third type, but also due to psychic externalities, too. Others say that merit goods are provided paternalistically and hence, in violation of the principle of consumer sovereignty, as a manifestation of the social responsibilities that a good government is supposed to have beyond the economic ones. The first viewpoint is consistent with our earlier discussion about the connection of consumer sovereignty with weak efficiency and the theory of second best. But, the second viewpoint implies that one can put the notion of consumer sovereignty in the service of some vague public/common interest, from dismissing it altogether to exalting it, to justify extreme positions about government-sector size. Positions, ranging from libertarian anarchism and unfettered capitalism to Hitlerite fascism and Stalinist communism.

\section{Globalization and the collapse of consumer sovereignty}

Consider the goods $\mathrm{x}$ in country A that are produced less costly relative to production by other countries. As A has a Comparative Advantage in producing $\mathrm{x}$, country $\mathrm{B}$ has such an advantage regarding goods $\mathrm{y}$, whose production in $\mathrm{A}$ would be costlier relative to production in B. So, it would benefit both $\mathrm{A}$ and $\mathrm{B}$ to exchange these goods and this how a system of international markets for $\mathrm{x}$ and $\mathrm{y}$ comes up. The Walrasian general equilibrium/disequilibrium "mechanics" are readily applicable to this system of markets as well, suffices trade to be as free as trade is within the borders of a given country. There ought to be free international flows of physical capital and free labor migration too, for the system to be complete. This freedom of trade and resource mobility is exactly what globalization supporters advocate towards the full integration of the global economy. Based on the first theorem of welfare economics, globalization will be welfare-enhancing, they claim. But, domestic and international markets are far from being competitive, let alone perfectly competitive. Also, the practice in labor markets is not one of free migration but of tapping cheaper foreign labor markets. And, if labor does try to migrate freely, it is difficult for the host population to tolerate centuries-old civilization gaps with the incoming migrants. Clearly, there is not consumer-laborer-voter sovereignty in the host country to the extent that its government is at variance with the wishes of its constituency.

And, even if there were perfect competition, there are not those national and international income reallocations that would make globalization a Pareto improvement over the non-globalization case, as the second theorem of welfare economics mandates. What we see instead is the rich becoming richer and the poor becoming poorer as in
Figure 2 below. Globalization has turned consumer-laborer-voter sovereignty into fiction.

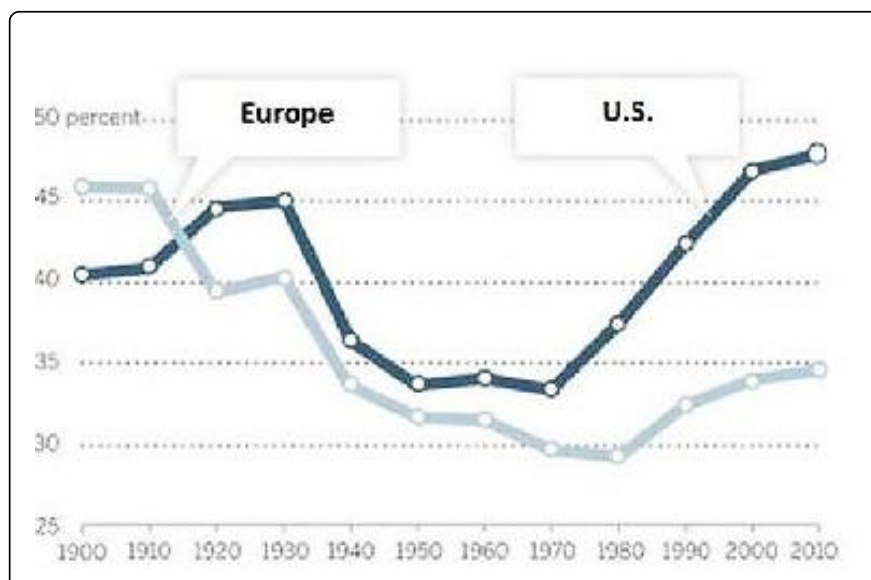

Figure 2: The Evolution of the Top 10\% Pre-tax Income Share in the U.S. and Europe between 1900 and 2010 [5].

\section{Would the socialist market outperform globalization?}

The socialist market is the system in which production is undertaken mostly by government-owned enterprises, but the outputs produced are let to be allocated by the markets. Lange and Lerner showed around 1938 that (contrary to globalization) such a system will satisfy both fundamental theorems of welfare economics if pricing coincides with the perfectly competitive one. That is, theoretically, the government in this system can produce goods as well as the free market system does. Consumer-laborer sovereignty is shared with the central production agency and not with the multinational capitalists of globalization, while voter sovereignty is as good as under the free market since the central government does not need to be shared with business corporations, minority groups, the media, etc., as globalization mandates. So, it appears that the socialist market outperforms globalization. Nevertheless, it would be politically a dangerous step to go from the free markets to socialist ones even as a desperate move to attain weak efficiency in the context of the theory of second best. The reason is that the strengthening of government powers could easily turn the socialist market to an autarchic variant of this system, such as the Soviet command-economy system was. A system, which collapsed noisily in 1991, with its prolonged despotism being one reason for its fall.

\section{In Conclusion: The Welfare State; The Practically Ideal System}

"Welfare state, concept of government in which the state or a wellestablished network of social institutions plays a key role in the protection and promotion of the economic and social well-being of citizens. It is based on the principles of equality of opportunity, equitable distribution of wealth, and public responsibility for those unable to avail themselves of the minimal provisions for a good life." "The sociologist Marshall [6], identified the welfare state as a distinctive combination of democracy, welfare and capitalism."

The welfare state lasted from the end of WWII until the late 1970s. It was the result of "the great fear among Western capitalist regimes that the working class in the West would "follow" (after the war) the 
Citation: Soldatos GT (2016) An Abridged Welfare-State Minded Introduction to the "Art" of Microeconomics. J Socialomics 5: 184. doi: 10.4172/2167-0358.1000184

Page 5 of 5

Soviet example (of Soviet-type collectivist-welfare reforms) or, at a minimum, support parties and actions which would undermine capitalis[m]."

The decline of the welfare state started with the neo-liberal Thatcherism in UK (late 1970s) and Reaganomics in USA (early 1980s). With the collapse of the Soviet Union in 1991, it gave way to globalization. "The development of a global economy has implications for national welfare policies. The nation state is being 'hollowed out', with power being dispersed to localities, independent organizations, and supra-national bodies (like NAFTA or the European Union). Mishra argues, in 'Globalization and the Welfare State' (2000), that globalization limits the capacity of nation-states to act for social protection. Global trends have been associated with a strong neoliberal ideology, promoting inequality and representing social protection as the source of 'rigidity' in the labor market. International organizations like the world bank and international monetary fund have been selling a particular brand of economic and social policy to developing countries, and the countries of Eastern Europe, focused on limited government expenditure, selective social services and private provision."

One central lesson from microeconomics is that as soon as there are merit goods, either we refuse their presence thereby denying their provision to people who need them as globalization does aiming at expanding the ranks of the weak, or we accept their presence and endorse the welfare-state, and turn a deaf ear to extreme political rhetoric exploiting the humanitarian character of such goods.

\section{Indeed:}

The "art" of economics: Economists study how societies try to solve their economic problem (positive analysis), develop solution theories, and propose based on them policies (normative statements) that may alter the nature of the economic problem fundamentally.

\section{References}

1. Adam S (1776) An inquiry into the nature and causes of the wealth of nations. University of Chicago Press.

2. Adam S (1759) The theory of moral sentiments. In: Haakonssen K (Ed). Cambridge University Press.

3. David R (1817) On the principles of political economy and taxation. London, UK.

4. Brams SJ, Jones MA, Klamler C (2013) N-person cake-cutting: There may be no perfect division. Am Math Monthly 120(1): 3-47.

5. Saez P (2014) Inequality in the long run. Science, 344(6186): 838-843.

6. Alfred M (1920) Principles of economics. Macmillan, London, UK. 